\title{
Reactions of $\mathrm{N}$-Ethylmaleimide with Peptides and Amino Acids
}

\author{
BY DEREK G. SMYTH \\ National Institute for Medical Research, Mill Hill, London, N.W. 7 \\ O. O. BLUMENFELD AND W. KONIGSBERG \\ Rockefeller Institute, New York 21, N.Y., U.S.A.
}

(Received 11 October 1963)

$N$-Ethylmaleimide (NEM) has been much used for the chemical modification of proteins, and it is usually assumed that reaction occurs specifically at the thiol groups of cysteinyl residues. However, NEM has been shown to react also with the $\alpha$ amino group of peptides and with the imidazole group of histidine (Smyth, Nagamatsu \& Fruton, $1960)$, and with the $\alpha$-amino group of certain amino acids (Smyth et al. 1960; Riggs, 1961). Since the reaction of NEM with some proteins is much slower than its reaction with the thiol group of cysteine (Gregory, 1955), the possibility should be considered that, when NEM reacts with proteins, groups other than thiol may be involved.

The present paper gives the rates of reaction of NEM with the $\alpha$-amino group of glycylalanine, with the $N$-terminal peptide of the $\alpha$-chain of haemoglobin and with the $N$-terminal peptide of the $\beta$-chain of haemoglobin. The results obtained emphasize the necessity for caution in the use of NEM as a specific reagent for thiol groups of proteins. In addition, a detailed investigation is reported on the hydrolysis of NEM addition products with cysteine, homocysteine, glutathione and reduced ribonuclease. The results obtained with these compounds are used to establish a new procedure for determining the extent of reaction of NEM with the thiol groups of a protein, and for assessing the specificity of the reaction.

\section{MATERIALS AND METHODS}

Glycyl-L-alanine was obtained from Mann Research Laboratories, New York 6, N.Y., U.S.A. Val-Leu-Ser-ProAla-Asp-Lys (T $\alpha-4$, the $N$-terminal peptide from the $\alpha$ chain of human haemoglobin), and Val-His-Leu-Thr-ProGlu-Glu-Lys (T $\beta-6$, the $N$-terminal peptide from the $\beta$ chain of human haemoglobin), were prepared from tryptic digests of the respective chains of globin as described by Guidotti, Hill \& Konigsberg (1962). The purity of all the peptides used was examined by chromatography both before and after acid hydrolysis. The addition product of NEM with L-cysteine and 2-( $N$-ethylcarbamoylmethyl)-3oxo- $2 H, 4 H, 5 H, 6 H-1,4$-thiazine-3-carboxylic acid were prepared as described by Smyth et al. (1960); the adducts with DL-homocysteine and glutathione were prepared by D. G. Smyth \& H. Tuppy (unpublished work), as described by Kermack \& Matheson (1957) for the latter compound.
S-(1,2-dicarboxyethyl)-L-cysteine. Attempts to obtain this derivative by the method of Morgan \& Friedmann (1938) did not yield a crystalline product. The derivative was therefore prepared from maleic anhydride instead of maleic acid. A similar method has been used by Calam \& Waley (1963), who isolated the compound as the cyclohexylamine salt.

L-Cysteine (41 m-moles, free base) was dissolved in oxygen-free water $(5 \mathrm{ml}$.). Maleic anhydride (50 m-moles) was added, and the solution was adjusted to $\mathrm{pH}$. A stream of nitrogen was bubbled through the solution for $2 \mathrm{hr}$. at room temperature. Chromatography of a sample of this solution showed no cysteine or $S$-(1,2-dicarboxyethyl)L-cysteine. The reaction mixture was diluted with $5 \mathrm{ml}$. of $0.2 \mathrm{~N}$-hydrochloric acid and was allowed to stand at $25^{\circ}$ for $4 \mathrm{hr}$. Automatic amino acid analysis of a sample revealed a nearly quantitative yield of $S$-(1,2-dicarboxyethyl)-Lcysteine, which was then crystallized from acetic acid in poor yield (Found: $\mathrm{C}, 35 \cdot 2 ; \mathrm{H}, 4.5 ; \mathrm{N}, 5 \cdot 7 . \mathrm{C}_{7} \mathrm{H}_{11} \mathrm{NO}_{6} \mathrm{~S}$ requires $\mathrm{C}, 35.5 ; \mathrm{H}, 4 \cdot 2 ; \mathrm{N}, 5.9 \%$ ). The synthetic compound was co-chromatographed with a 72-hr. acid hydrolysate of $S$-(1-ethyl-2,5-dioxopyrrolidin-3-yl)-L-cysteine, and a single peak was observed on elution from the $150 \mathrm{~cm}$. column of the Spinco amino acid analyser: Its elution position from this column, operated at $50^{\circ}$ with $0 \cdot 2 \mathrm{M}$-sodium citrate, pH 3.25, as eluent occurred at $102 \mathrm{ml}$. (Fig. 1), preceding $S$-carboxymethylcysteine. The integration constant was 21.4 relative to 19.7 for aspartic acid. Ethylamine was eluted at $109 \mathrm{ml}$. (between ammonia and arginine) from the $15 \mathrm{~cm}$. column at $50^{\circ}$ with $0 \cdot 35 \mathrm{M}$-sodium citrate buffer, pH 5.28, as eluent; its integration constant was 8.3. No decomposition of ethylamine occurred on exposure to $6 \mathrm{~N}-\mathrm{hyd}$ drochloric acid at $110^{\circ}$ for $72 \mathrm{hr}$.

N-Ethylmaleimide derivative of reduced ribonuclease. Ribonuclease A (Worthington Chemical Corp.) was reduced essentially as described by Crestfield, Moore \& Stein (1963). The protein (50 mg.) was dissolved in $20 \mathrm{ml}$. of $0.2 \mathrm{M}$-sodium phosphate buffer, $\mathrm{pH} 8.0$, and urea (9.6 g.) and 2-mercaptoethanol $(0.1 \mathrm{ml}$.) were added. The solution was maintained at $25^{\circ}$ for $3 \mathrm{hr}$. in a screw-top bottle from which air had been displaced by a stream of nitrogen. The solution was adjusted to $\mathrm{pH} 7 \cdot 0$, NEM (188 mg.) was added with magnetic stirring, and the reaction was allowed to proceed (15 min., $\left.25^{\circ}\right)$. The reaction was stopped $(1 \mathrm{ml}$. of acetic acid), and the alkylated protein separated from reagents by gel filtration on a column $(40 \mathrm{~cm} . \times 4 \mathrm{~cm}$.) of Sephadex G 25 and eluted with 50\% acetic acid. Appropriate fractions were combined, and freeze-drying yielded a white powder (43 mg.). Acid hydrolysis was carried out at $110^{\circ}$ for 22 and $72 \mathrm{hr}$, and the hydrolysates were subjected to quantitative amino acid analysis (Fig. 1). 
Ninhydrin analyses were performed by the manual method of Moore \& Stein (1954), and automatic amino acid analyses were performed with a Beckmann Spinco instrument by the method of Spackmann, Stein \& Moore (1958). Solutions were prepared for acid hydrolysis in $6 \mathrm{~N}$-hydrochloric acid, and were carefully deaerated in sealed evacuated tubes (Crestfield et al. 1963). The conditions of hydrolysis are recorded in the Results section.

\section{RESULTS}

Reaction of N-ethylmaleimide with glycyl-Lalanine. Preliminary experiments to determine the rate of reaction by direct ninhydrin analysis of a solution containing the dipeptide (1 mM) and NEM

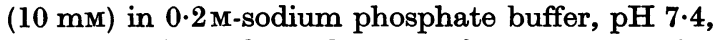
indicated that after $2 \mathrm{hr}$. at $37^{\circ}$ an apparent increase in the concentration of amino groups had occurred. However, when a control experiment was performed on a solution containing only the maleimide, rapidly increasing 'blank' values were observed, probably associated with the formation of $N$-ethylmaleamic acid by slow hydrolysis of NEM (cf. Gregory, 1955).

To measure the rate of reaction of the peptide with NEM, portions of the reaction mixture were acidified and chromatographed at $50^{\circ}$ on a column $(15 \mathrm{~cm} . \times 0.9 \mathrm{~cm}$.) of Amberlite IR-120 of an automatic amino acid analyser. With $0.2 \mathrm{M}$-sodium citrate buffer, pH 3.25, as eluent, the peptide emerged at $14 \mathrm{ml}$. After incubation for $1.2 \mathrm{hr}$., $50 \%$ of the initial amount of peptide remained. Since the reaction takes place at the $\alpha$-amino group of the peptide, the reaction product is ninhydrinnegative and is not observed. The reaction was investigated further by submitting samples of the reaction mixture to hydrolysis for $16 \mathrm{hr}$. in $6 \mathrm{~N}$ hydrochloric acid at $110^{\circ}$ and measuring the amounts of amino acids released. After treatment with NEM for $1 \mathrm{hr}$., the peptide mixture was hydrolysed and yielded one-half as much glycine as alanine. After reaction for $16 \mathrm{hr}$, the peptide
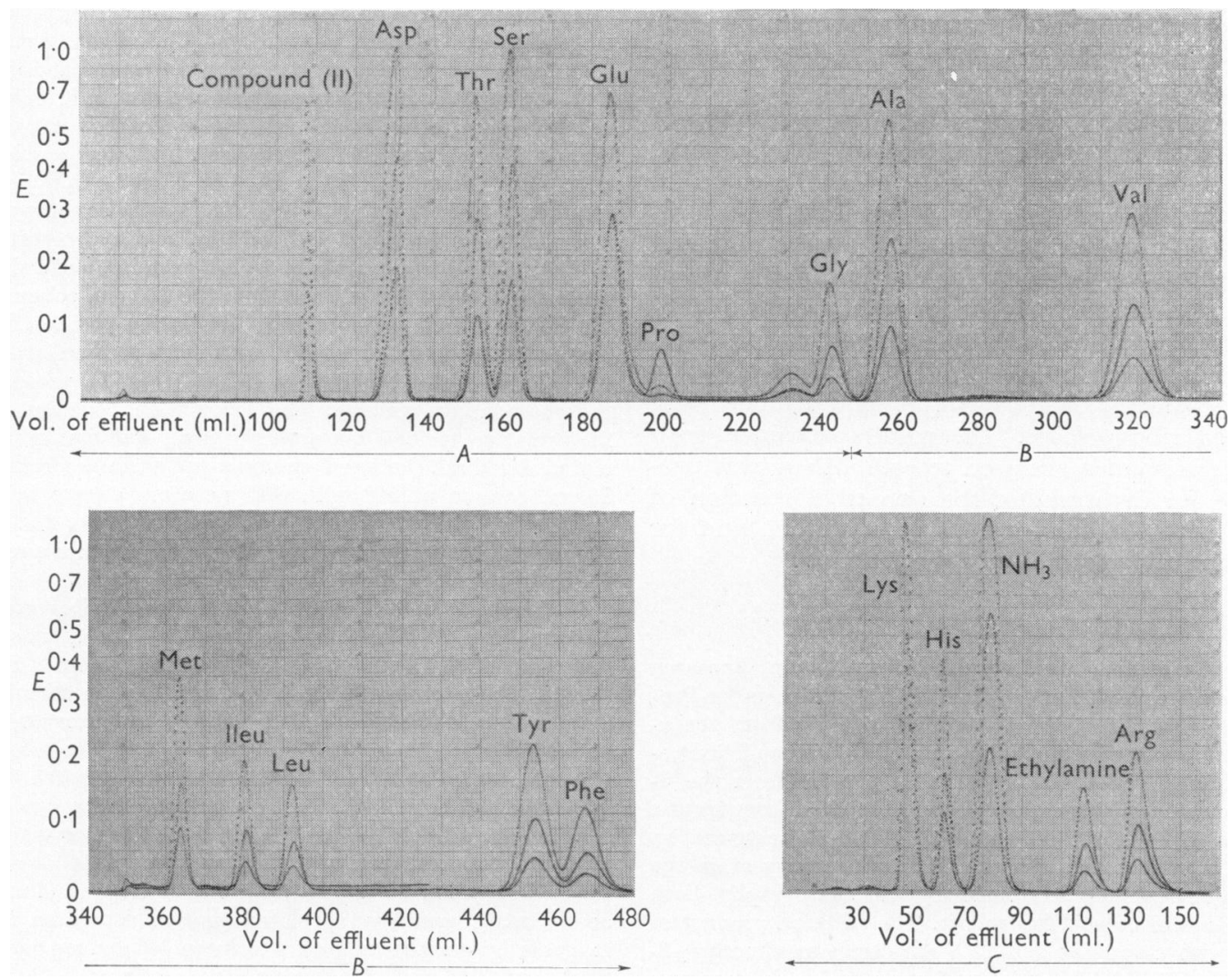

Fig. 1. Chromatographic analysis of a $22 \mathrm{hr}$. acid hydrolysate of the NEM derivative of reduced ribonuclease by the method of Spackman et al. (1958). $A, 150 \mathrm{~cm}$. column, eluted with $0.2 \mathrm{M}$-sodium citrate buffer, pH 3.25; $B, 150 \mathrm{~cm}$. column, eluted with $0 \cdot 2 \mathrm{M}$-sodium citrate buffer, $\mathrm{pH} 4 \cdot 25 ; C, 15 \mathrm{~cm}$. column, eluted with $0 \cdot 35 \mathrm{M}$-sodium citrate buffer, $\mathrm{pH} 5 \cdot 28$. In a $72 \mathrm{hr}$. hydrolysate, the two peaks between proline and glycine were not apparent. 
mixture gave on hydrolysis no glycine, the expected amount of alanine, and a small amount of a product moving ahead of glycine on chromatography. The rate of disappearance of glycine (compared with alanine) was found to equal the rate of disappearance of the dipeptide when analysed before hydrolysis.

It seems probable that the reaction involves addition of the peptide $\alpha$-amino group to the olefinic double bond of NEM, without opening of the imide ring. Tawney et al. (1961) have shown that base-catalysed polymerization of NEM is initiated by an addition at the double bond of NEM, and the resulting polymer retains the imide ring intact. Smyth et al. (1960) suggested that the amino group of a peptide may undergo a transamidation reaction involving the imide ring of NEM. In that case, the reaction product, an $N$-acylated peptide, would be expected to yield equal amounts of glycine and alanine on hydrolysis. In addition, the ultraviolet-absorption spectrum of the reaction product of NEM with glycylalanine exhibits an inflexion in the region of $240 \mathrm{~m} \mu$, similar to that exhibited by succinimide; the product is therefore considered to be $N$-(1-ethyl-2,5-dioxopyrrolidin-3yl)glycyl-I-alanine.

The reaction of glycylalanine with NEM was performed on a preparative scale. The product was isolated after chromatography of the reaction mixture at $35^{\circ}$ on a column $(20 \mathrm{~cm} . \times 2 \mathrm{~cm}$.) of Dowex 1 (X2) followed by rechromatography on Dowex 50 (X8) with 0.2 M-pyridinium formate buffer, pH 3.25, as eluent. The peptide derivative emerged at column volume from the latter column and was ninhydrin-negative. The peak was located by alkaline hydrolysis and ninhydrin analysis. After removal of the volatile solvent, a pale-yellow oil was obtained which failed to crystallize. The difficulty in attempted crystallization of $N$-(1-ethyl-2,5-dioxopyrrolidin-3yl)glycyl-I-alanine, as well as the difficulty in crystallizing $S$-(1,2-dicarboxyethyl)-x-cysteine, may be due to the presence of diastereoisomeric forms of each derivative (see below).

Reaction of N-ethylmaleimide with peptide $T \alpha-4$ (Val-Leu-Ser-Pro-Ala-Asp-Lys). The reaction was performed with NEM (10 mM) and peptide ( $1 \mathrm{~mm}$ ) in $0.2 \mathrm{M}$-sodium phosphate buffer, pH $7 \cdot 4$, at $25^{\circ}$. The rate of disappearance of the peptide was measured by analysis of portions of the reaction mixture at pH 5.28 on the $15 \mathrm{~cm}$. column of the analyser; the half-life of the peptide was $3.2 \mathrm{hr}$. As the reaction proceeded, a new peak appeared at column volume and increased until it reached a value one-half that of the unchanged peptide. This derivative is probably formed by alkylation of the $N$-terminal valine residue, and still possesses a free $\epsilon$-amino group on the $C$-terminal lysine residue.
Before treatment with NEM, the peptide was hydrolysed for $72 \mathrm{hr}$. in $6 \mathrm{~N}$-hydrochloric acid at $110^{\circ}$ and the following composition (molar ratios of constituent amino acids) was observed: Lys, 1.05; Asp, 1.21; Ser, 0.90; Pro, 1.04; Ala, 1.00; Val, 1.04; Leu, 0.96. After reaction with NEM for $12 \mathrm{hr}$., the reaction mixture was hydrolysed as described above and its composition was: $\mathrm{Lys}, 0.93$; Asp, 1.14; Ser, 0.87; Pro, 1.06; Ala, 1.00; Val, 0.20; Leu, $\mathbf{0 \cdot 8 3}$.

Reaction of N-ethylmaleimide with peptide $T \beta-6$ (Val-His-Leu-Thr-Pro-Glu-Glu-Lys). Under the same reaction conditions as above, the rate of disappearance of peptide showed it to have a halflife of $2.5 \mathrm{hr}$. Before reaction, the peptide was hydrolysed and the following composition was observed: Lys, 0.99; His, 0.93; Thr, 0.90; Glu, 1.94; Pro, 1.05 ; Val 0.97 ; Leu, $1 \cdot 00$. After reaction with NEM for $8 \mathrm{hr}$., the reaction mixture was hydrolysed and its composition was: Lys, 0.93 ; His, 0.86 ; Thr, 0.87; Glu, 1.92; Pro, 1.03; Val, 0.18; Leu, 1.00.

Reaction of N-ethylmaleimide with L-cysteine. On automatic amino acid analysis of an analytically pure sample of $S$-(1-ethyl-2,5-dioxopyrrolidin-3yl)-L-cysteine (I), two peaks were observed with a marked elevation of the base line between the

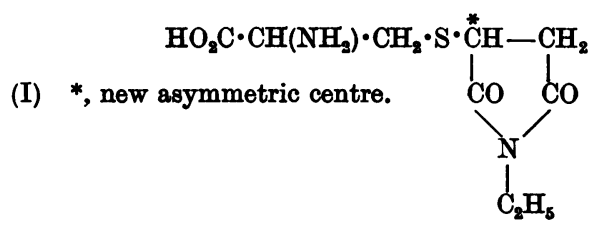

peaks. Their separation on a column $(150 \mathrm{~cm} . \times$ $0.9 \mathrm{~cm}$.) of Amberlite IR-120 developed with $0.2 \mathrm{M}$-sodium citrate buffer, $\mathrm{pH} 3 \cdot 25$, at $50^{\circ}$ included $45 \mathrm{ml}$. of eluent (Fig. 2). When compound (I) was co-chromatographed with a standard mixture of amino acids, the first peak overlapped proline and the second preceded glycine. The amount of ninhydrin-positive material chromatographing between the two peaks was found to depend on the length of the column and the temperature of the eluent. On the $150 \mathrm{~cm}$. column at $50^{\circ}$, about $15 \%$ of compound (I) appeared between the peaks. When a $15 \mathrm{~cm}$. column at $30^{\circ}$ was used, the two peaks were clearly resolved, and no significant elevation of the base line was seen. Preliminary heating of a solution of compound (I) at $\mathrm{pH} 3 \cdot 25$ and $50^{\circ}$ for $16 \mathrm{hr}$. resulted in no change in elution pattern obtained on subsequent chromatography in either system.

Isolation of each of the two compounds was achieved on a column (60 cm. $\times 2 \mathrm{~cm}$.) of Dowex 50 (X8), developed with $0.2 \mathrm{~m}$-pyridinium formate buffer, $\mathrm{pH} 3 \cdot 25$, at $4^{\circ}$; solvent was removed by freeze-drying. Each derivative was examined for purity by rechromatography of a portion at $30^{\circ}$ on 
a $15 \mathrm{~cm}$. column of the automatic analyser, and each gave a single peak. On rechromatography at $\mathrm{pH} 3.25$ and $50^{\circ}$ on a $150 \mathrm{~cm}$. column, the results shown in Fig. 3 were obtained. Interconversion of each derivative is clearly demonstrated. Heating of each compound for $2 \mathrm{hr}$. in $0.2 \mathrm{M}$-sodium citrate buffer, $\mathrm{pH} 3 \cdot 25$, at $50^{\circ}$, followed by chromatography at $30^{\circ}$, showed the presence in each solution of both derivatives. The results of elemental analysis of these compounds, as well as their ready interconversion, show that they are diastereoisomeric forms of $S$-(1-ethyl-2,5-dioxopyrrolidin-3yl)-L-cysteine, the second asymmetric centre being generated as a result of addition of the thiol to the olefinic double bond of NEM.

The finding of two products after the reaction of NEM with L-cysteine calls attention to the probability that the product obtained by reaction of NEM with the thiol groups of a protein will exist also in more than one form, and attempts to chromatograph NEM-treated proteins or peptides may result in the interconversion of the isomers during the manipulation.

Acid hydrolysis of N-ethylmaleimide derivatives of L-cysteine. The considerable stability of compound (I) toward acid is apparent from the results shown

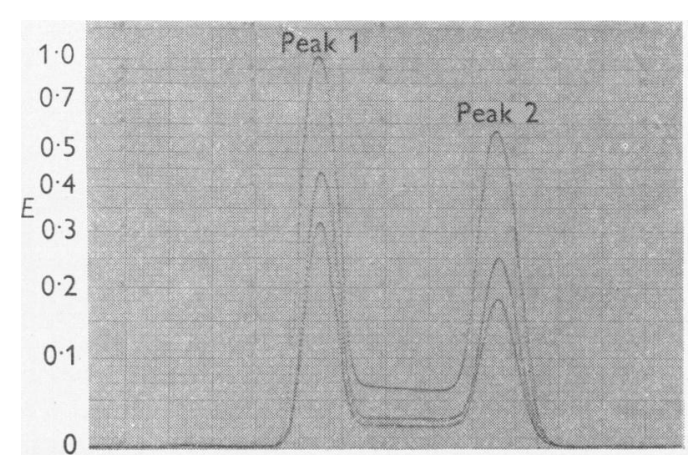

Fig. 2. Chromatographic analysis of $S$-(1-ethyl-2,5-dioxopyrrolidin-3-yl)-L-cysteine (I). The solution was prepared for chromatography by dissolving $5 \mathrm{mg}$. of compound (I) in $10 \mathrm{ml}$. of $0.2 \mathrm{M}$-sodium citrate buffer, $\mathrm{pH} 2 \cdot 2$; a $1 \mathrm{ml}$. sample was analysed on a $150 \mathrm{~cm}$. column of Amberlite IR-120 at $50^{\circ}$. in Table 1. The product of hydrolysis was identified by co-chromatography with a synthetic sample of $S$-(1,2-dicarboxyethyl)-L-cysteine (II) prepared by

$$
\mathrm{HO}_{2} \mathrm{C} \cdot \mathrm{CH}\left(\mathrm{NH}_{2}\right) \cdot \stackrel{*}{\mathrm{C}} \mathrm{H}_{2} \cdot \mathrm{S} \cdot \mathrm{CH}\left(\mathrm{CO}_{2} \mathrm{H}\right) \cdot \mathrm{CH}_{2} \cdot \mathrm{CO}_{2} \mathrm{H}
$$

reaction of maleic anhydride with L-cysteine, followed by hydrolysis. Though an $88 \%$ yield of compound (II) was obtained after $72 \mathrm{hr}$. at $110^{\circ}$ in $6 \mathrm{~N}$-hydrochloric acid, at no time was the intermediate, $S$-[(1-carboxy-2- $N$-ethylcarbamoyl)ethyl]L-cysteine (III) detected in the hydrolysate. This
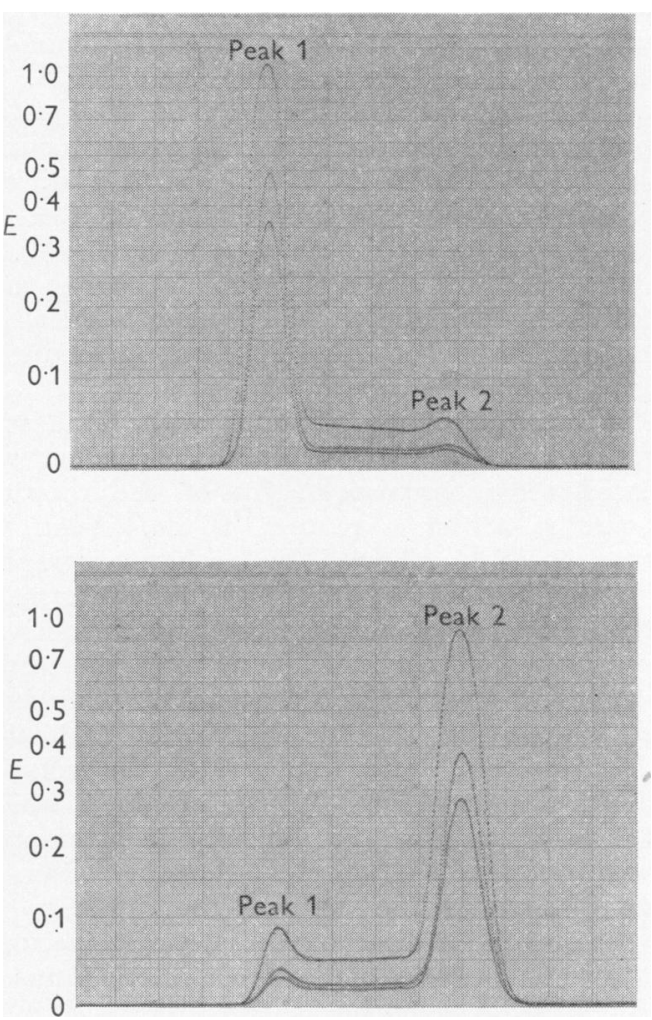

Fig. 3. Chromatographic analysis of diastereoisomers of S-(1-ethyl-2,5-dioxopyrrolidin-3-yl)-L-cysteine (I). Each solution was chromatographed as described in Fig. 2.

Table 1. Hydrolysis of S-(1-ethyl-2,5-dioxopyrrolidin-3-yl)-L-cysteine (I) in $6 \mathrm{~N}$-hydrochloric acid

In each analysis, the products obtained from $0.92 \mu$ mole of compound $(I)$ were determined as indicated in the text. The amount of residual compound (I) was estimated by summation of the two isomers.

\begin{tabular}{|c|c|c|c|c|c|}
\hline Temp. & $\begin{array}{c}\text { Duration of } \\
\text { hydrolysis } \\
\text { (hr.) }\end{array}$ & $\underset{(\mu \text { mole })}{\text { Residual }}$ & $\begin{array}{c}\text { Compound (II) } \\
\text { formed } \\
(\mu \text { mole })\end{array}$ & $\begin{array}{c}\text { Ethylamine } \\
\text { formed } \\
(\mu \text { mole })\end{array}$ & $\begin{array}{c}\text { Yield of } \\
\text { compound (II) } \\
(\%)\end{array}$ \\
\hline $\begin{array}{l}105^{\circ} \\
105 \\
110\end{array}$ & $\begin{array}{l}22 \\
72 \\
72\end{array}$ & $\begin{array}{l}0.53 \\
0.16 \\
0.07\end{array}$ & $\begin{array}{l}0 \cdot 35 \\
0 \cdot 76 \\
0 \cdot 81\end{array}$ & $\begin{array}{l}0.36 \\
0 \cdot 76 \\
0 \cdot 78\end{array}$ & $\begin{array}{l}38 \\
83 \\
88\end{array}$ \\
\hline
\end{tabular}


Table 2. Hydrolysis of 2-(N-ethylcarbamoylmethyl)-3-oxo-2H,4H,5H,6H-1,4-thiazine-3-carboxylic acid (IV) in 6-N-hydrochloric acid at $105^{\circ}$

In each analysis, the products obtained from $0.63 \mu$ mole of compound (IV) were determined as indicated in the text.

$\begin{array}{ccc}\begin{array}{c}\text { Time of } \\ \text { hydrolysis } \\ \text { (hr.) }\end{array} & \begin{array}{c}\text { Compound (I) } \\ \text { formed } \\ (\mu \text { mole })\end{array} & \begin{array}{c}\text { Compound (II) } \\ \text { formed } \\ (\mu \text { mole })\end{array} \\ 8 & 0 \cdot 41 & 0.20 \\ 22 & 0.33 & 0.28 \\ 72 & 0.07 & 0.56\end{array}$

$\begin{gathered}\text { Ethylamine } \\ \text { formed } \\ (\mu \text { mole })\end{gathered}$
$0 \cdot 25$
$0 \cdot 34$
$0 \cdot 63$

Yield of compound (II)

derivative, produced by exposure of compound (I) to $0 \cdot 1 \mathrm{~N}$-sodium hydroxide, underwent cyclization very rapidly in acid solution at $100^{\circ}$, re-forming the imide ring of the two isomers of compound (I). Thus acid hydrolysis of compound (I) probably involves the formation of compound (III) followed by an unfavourable hydrolytic cleavage in competition with the cyclization reaction. As was expected, the release of ethylamine during the acid hydrolysis of compound (I) occurred at the same rate as the formation of compound (II).

$$
\mathrm{HO}_{2} \mathrm{C} \cdot \mathrm{CH}\left(\mathrm{NH}_{2}\right) \cdot \mathrm{CH}_{2} \cdot \mathrm{S} \cdot \stackrel{\mathrm{C}}{\mathrm{CH}}\left(\mathrm{CO}_{2} \mathrm{H}\right) \cdot \mathrm{CH}_{2} \cdot \mathrm{CO} \cdot \mathrm{NH} \cdot \mathrm{C}_{2} \mathrm{H}_{5}
$$

In all acid hydrolysates of compound (I), the sum of the amounts of compound (II) and residual compound (I) accounts for the amount of compound (I) subjected to hydrolysis; therefore compound (I) does not undergo a transamidation reaction to a ninhydrin-negative product, 2 - $(N$-ethylcarbamoylmethyl) - 3 - oxo- $2 H, 4 H, 5 \mathrm{H}, 6 \mathrm{H}$ - 1,4 - thiazine-3-carboxylic acid (IV), under these acid condi-

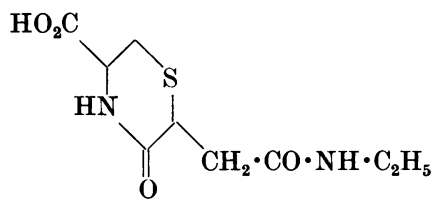

(IV)

tions. This intramolecular rearrangement has previously been reported to occur when compound (I) is exposed to very mild alkaline conditions (Smyth et al. 1960); a similar transamidation occurs after the reaction of bovine serum albumin with dimethylaminodinitrophenylmaleimide (Witter \& Tuppy, 1960). With the adduct derived from this maleimide and cysteine, a thiazine derivative forms rapidly on solution at $\mathrm{pH} 6$. In view of the possibility of formation of thiazine derivatives resulting from treatment of proteins with NEM, we have investigated the hydrolysis of the model compound (IV). The ninhydrin-positive reaction products were determined by automatic amino acid analysis (Table 2). Exposure of compound (IV) to $6 \mathrm{~N}$-hydrochloric acid resulted in the formation of the two isomers of the cyclic imide (I). Con- tinued hydrolysis of this mixture resulted in a slow formation of compound (II), though more rapidly than is formed on acid hydrolysis of compound (I). There appear to be two hydrolytic pathways leading to the formation of compound (II) ; first, by formation of compound (I) and its subsequent hydrolysis to compound (II) as above, and, secondly, by the formation of a ninhydrin-negative intermediate (V), not directly measured, followed by its subsequent hydrolysis to compound (II). In agreement with this possibility, during the hydrolysis of compound (IV) ethylamine was released more rapidly than $S$-(1,2-dicarboxyethyl)-L-cysteine.<smiles>O=C(O)CC1SCC(C(=O)O)NC1=O</smiles>

(V)

Acid hydrolysis of S-(1-ethyl-2,5-dioxopyrrolidin3-yl)-DL-homocysteine. This compound exhibits a degree of stability towards acid, similar to that observed with compound (I) (Table 3). The intermediate, $S-[(1$-carboxy-2- $N$-ethylcarbamoyl)ethyl $]$ DL-homocysteine, wasnot detected in a 22-hr. hydrolysate; the rate of appearance of ethylamine was equal to the rate of formation of $S$-(1,2-dicarboxyethyl)-DL-homocysteine. The latter derivative, seen as a fast-moving ninhydrin-positive product, was determined by ion-exchange chromatography. It was not synthesized independently, but was assumed to be $S$-(1,2-dicarboxyethyl)-DL-homocysteine by analogy with the formation of compound (II) on acid hydrolysis of compound (I).

Acid hydrolysis of S-(1-ethyl-2,5-dioxopyrrolidin3-yl)glutathione. This compound readily undergoes hydrolysis to glutamic acid, glycine and $S$-(1-ethyl2,5-dioxopyrrolidin-3-yl)-L-cysteine (I). The latter then slowly gives rise to compound (II), as described above. Again, ethylamine was released at a rate equal to the rate of appearance of $S-(1,2-$ dicarboxyethyl)-L-cysteine (Table 3).

Acid hydrolysis of the N-ethylmaleimide derivative of reduced ribonuclease. In a 22-hr. hydrolysate, 


\section{Table 3. Hydrolysis of the addition products of $\mathrm{N}$-ethylmaleimide with glutathione, reduced ribonuclease} and DL-homocysteine in $6 \mathrm{~N}$-hydrochloric acid at $110^{\circ}$

Experimental details are indicated in the text. Expt. 1: In the 22-hr. hydrolysate, 0.42 $\mu$ mole of compound (I) was found: in both analyses, the expected values of glycine and glutamic acid were obtained. Expt. 2: Ribonuclease contains 4 cystine residues/molecule; thus $0.091 \mu$ mole of reduced protein should yield $0.73 \mu$ mole of cysteine; the residual compound (I) present in the 22-hr. hydrolysate could not be determined because of overlapping with proline and glycine. Expt. 3 : In the 22-hr. hydrolysate, $0 \cdot 48 \mu$ mole of $S$-(1-ethyl-2,5-dioxopyrrolidin3-yl)homocysteine was found.

$\begin{array}{cccccc}\begin{array}{c}\text { Expt. } \\ \text { no. }\end{array} & \text { NEM derivative } & \begin{array}{c}\text { Duration of } \\ \text { hydrolysis } \\ (\mathrm{hr} .)\end{array} & \begin{array}{c}\text { Ethylamine } \\ \text { formed } \\ (\mu \text { mole })\end{array} & \begin{array}{c}\text { Compound (II) } \\ \text { formed } \\ (\mu \text { mole) }\end{array} & \begin{array}{c}\text { Yield of } \\ \text { compound (II) } \\ (\%)\end{array} \\ 1 & \text { Glutathione-NEM adduct } & 22 & 0 \cdot 41 & 0 \cdot 40 & 46 \\ & \text { (0.87 } \mu \text { mole) } & 72 & 0.74 & 0 \cdot 74 & 85 \\ 2 & \text { Reduced ribonuclease-NEM adduct } & 22 & 0 \cdot 41 & 0 \cdot 42 & 88 \\ & \text { (0.091 } \mu \text { mole) } & 72 & 0 \cdot 64 & 0 \cdot 63 & 86 \\ 3 & \text { Homocysteine-NEM adduct } & 22 & 0 \cdot 41 & 0 \cdot 40^{*} & 42 \\ & \text { (0.95 } \mu \text { mole) } & 72 & 0 \cdot 79 & 0 \cdot 79^{*} & 83\end{array}$

* $S$-(1,2-Dicarboxyethyl)-DL-homocysteine, the ninhydrin colour value of which was assumed to be the same as that for compound (II).

poor yields of $S$-(1,2-dicarboxyethyl)-L-cysteine and ethylamine were obtained (Table 3 ) and a considerable amount of $S$-(1-ethyl-2,5-dioxopyrrolidin3-yl)-L-cysteine was present (Fig. 1). After $72 \mathrm{hr}$. at $110^{\circ}$, an $86 \%$ yield of $S$-(1,2-dicarboxyethyl)-Lcysteine was found. Since ethylamine appeared in an amount equal to the amount of $S$-(1,2-dicarboxyethyl)-L-cysteine, the initial addition reaction of NEM to the reduced protein must, under the conditions used, have been specific for cysteine residues. However, the protein was exposed only briefly to the reagent, the $\mathrm{pH}$ of the reaction did not rise above neutrality and, with respect to the total free thiol groups in the reduction mixture, only a moderate excess of reagent was employed.

Alkaline hydrolysis of S-(1-ethyl-2,5-dioxopyrrolidin-3-yl)-L-cysteine. Exposure of compound (I) to very mild alkaline conditions $(\mathrm{pH} 8)$ results in formation of the thiazine (IV). Exposure of compound (I) to strong base ( $\mathrm{N}$-sodium hydroxide) at $100^{\circ}$ for $1 \mathrm{hr}$. results in the formation of a number of products including cysteine, cystine and cysteic acid, presumably by a reversal of the addition reaction involved in the synthesis of compound (I). However, intermediate conditions of hydrolysis $\left(0 \cdot 1 \mathrm{~N}\right.$-sodium hydroxide at $\left.25^{\circ}\right)$ results in instantaneous formation of compound (III) followed extremely slowly by the release of $S$-(1,2-dicarboxyethyl)-L-cysteine. Possibly the negatively charged carboxyl group of compound (III) repels the approach of $\mathrm{OH}^{-}$ions necessary for further hydrolysis.

\section{DISCUSSION}

Of the conditions examined, the most favourable for the hydrolysis of NEM-modified proteins is a $72 \mathrm{hr}$. exposure to $6 \mathrm{~N}$-hydrochloric acid at $110^{\circ}$. To obtain reproducible yields, it is essential to exclude air rigorously during the preparation of the acid solution for hydrolysis. S-(1,2-Dicarboxyethyl)-Lcysteine, formed in $86 \%$ yield, is determined by ion-exchange chromatography and is related to the amount of a known stable amino acid as an internal standard. Ethylamine is formed on hydrolysis after reaction of NEM with either amino or thiol groups ; $S$-(1,2-dicarboxyethyl)-L-cysteine is formed on hydrolysis only after reaction at thiol groups. A comparison between the amounts of ethylamine and of $S$-(1,2-dicarboxyethyl)-L-cysteine in an acid hydrolysate of an NEM-treated protein provides a quantitative measurement of the specificity of the reagent towards thiol groups. Thus, when NEM reacts specifically with thiol groups, the yields of ethylamine and of $S$-(1,2-dicarboxyethyl)-Lcysteine are equal; when reaction occurs also at amino groups, the molar ratio of ethylamine to $S$-(1,2-dicarboxyethyl)-L-cysteine is greater than 1 . Since ethylamine can also arise on hydrolysis of the reagent, the protein must be completely separated from excess of NEM before being submitted to hydrolysis.

These studies provide a basis for the consideration of reactions to be expected between NEM and proteins. The reaction of NEM with the $\alpha$-amino groups of peptides takes place under mild conditions and at significant rates compared with those observed for the reaction of NEM with some proteins. To favour specificity of NEM towards thiol groups, reaction mixtures should be maintained below neutrality and excess of the reagent should be avoided. Under these conditions, the reagent exhibits a high degree of specificity for thiol groups.

The question of specificity of a reagent is one that should be treated as a separate problem with each protein under investigation. On the one hand, 
the folding of a peptide chain within a protein may decrease the reactivity of $\alpha$ - or $\epsilon$-amino groups by rendering them less accessible; on the other hand, charged groups may be close to a particular amino or imidazole group, and thereby enhance its reactivity. The distinction between 'reactive' and 'unreactive' groups in a protein is best established by a careful investigation, preferably involving degradation of the modified protein and analytical studies on the isolated peptides. In this way, the extent and sites of a reaction can be determined with precision. Methods involving measurement of the disappearance of the reagent (Alexander, 1958), in contradistinction to measurement of the formation of a derivative, provide only circumstantial information on the nature of the reaction.

\section{SUMMARY}

1. The rates of reaction of $N$-ethylmaleimide with the $\alpha$-amino groups of three peptides are reported.

2. Some observations are presented on the isomerism of the addition products of $N$-ethylmaleimide with thiol compounds.

3. A detailed analysis of the products of hydrolysis of these derivatives has been performed. A method for the determination of the degree of reaction of $N$-ethylmaleimide with the thiol groups of proteins is proposed, together with a means of assessing the specificity of the reaction.
4. The results are of significance in the use of $N$-ethylmaleimide as a reagent for the introduction of chemical modifications in proteins.

The authors thank Dr W. H. Stein, Dr S. Moore, Dr L. Craig and Dr G. Guidotti of the Rockefeller Institute, and Dr J. S. Fruton of Yale University, for valuable discussion and assistance. The work was supported in part by Grant no. A-2493 from the U.S. Public Health Service.

\section{REFERENCES}

Alexander, N. M. (1958). Analyt. Chem. 30, 1292.

Calam, D. H. \& Waley, S. G. (1963). Biochem. J. 86, 226.

Crestfield, A. M., Moore, S. \& Stein, W. H. (1963). J. biol. Chem. 238, 622.

Gregory, J. D. (1955). J. Amer. chem. Soc. 77, 3922.

Guidotti, G., Hill, R. J. \& Konigsberg, W. (1962). J. biol. Chem. 237, 2184.

Kermack, W. O. \& Matheson, M. A. (1957). Biochem. J.65, 45.

Moore, S. \& Stein, W. H. (1954). J. biol. Chem. 211, 907.

Morgan, E. J. \& Friedmann, E. (1938). Biochem. J. 32, 733.

Riggs, A. (1961). J. biol. Chem. 236, 1948.

Smyth, D. G., Nagamatsu, A. \& Fruton, J. S. (1960). J. Amer. chem. Soc. 82, 4600.

Spackmann, D. H., Stein, W. H. \& Moore, S. (1958). Analyt. Chem. 30, 1190.

Tawney, P. O., Snyder, R. H., Conger, R. P., Leibbrand, K. A., Stitcher, C. H. \& Williams, A. R. (1961). J. org. Chem. 26, 15.

Witter, A. \& Tuppy, H. (1960). Biochim. biophys. Acta, 45, 429.

Biochem. J. (1964), 91, 595

\title{
Development of Respiration in Yeast Grown Anaerobically on Different Carbon Sources
}

\author{
BY E. R. TUSTANOFF* AND W. BARTLEY $\dagger$ \\ Department of Biochemistry, University of Oxford
}

(Received 18 October 1963)

This paper describes the aerobic behaviour of yeast, previously grown anaerobically on a number of different carbon sources. The results show that yeast grown anaerobically on galactose retains its respiratory activity whereas the yeast grown similarly on glucose loses it.

\footnotetext{
* Present address: Research Institute of the Hospital for Sick Children, 555 University Avenue, Toronto, Canada.

$\dagger$ Present address: Department of Biochemistry, University of Sheffield, Sheffield 10.
}

\section{METHODS}

Maintenance and growth of yeast. Saccharomyces cerevisiae strain no. 77 of the National Collection of Yeast Cultures (Brewing Industry Research Foundation, Nutfield, Surrey) was used in the present work. The organism was maintained aerobically on agar slopes containing inorganic salts, $2.25 \%$ (w/v) of Difco malt extract, $0.05 \%$ of Difco yeast extract and $0.5 \%$ of sucrose. The yeast was grown for $48 \mathrm{hr}$. at $30^{\circ}$ and subcultured monthly.

Growth of anaerobic cells. The medium for the anaerobic bulk growth of the yeast contained (per l.): glucose, $20 \mathrm{~g}$.; 